"مجله علوم زراعى ايران"

جلد بيست و يكم، شماره ا، بهار ائوان"

مقاله يثزوهشى

اثر الكوى كاشت و منبع كود بر خصوصيات زراعى بزركى (Linum usitatissimum L.) و نخود (Cicer arietinum L.)

Effect of planting pattern and fertilizer source on agronomic characteristics of linseed (Linum usitatissimum $\mathrm{L}_{\text {.) }}$ and chickpea (Cicer arietinum $\mathrm{L}_{\text {.) }}$ in intercropping under rainfed conditions

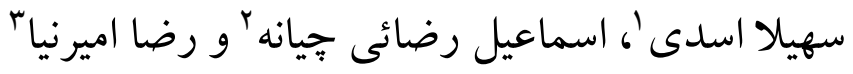

$$
\text { جكيده }
$$

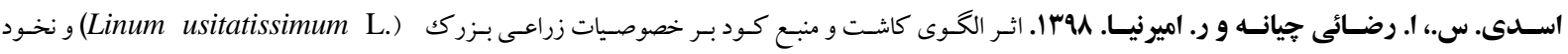
(Cicer arietinum L.)

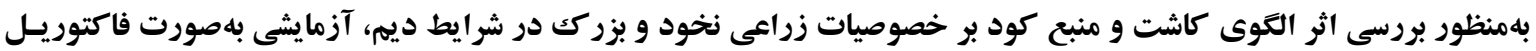

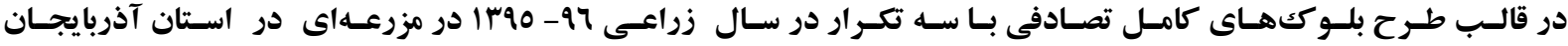

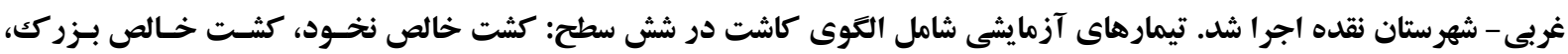

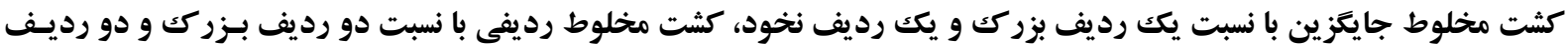

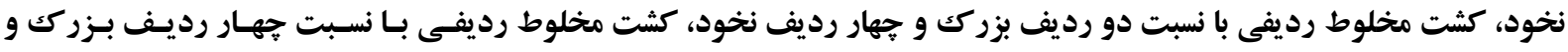

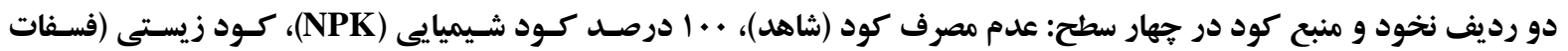

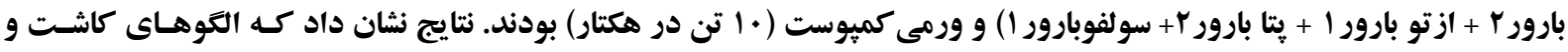

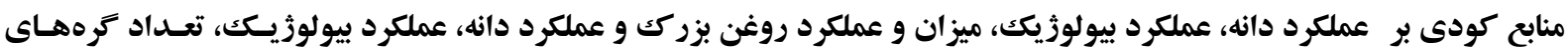

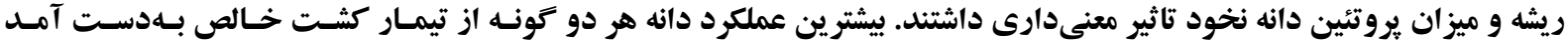

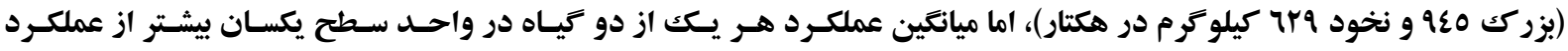

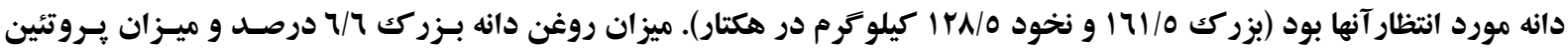

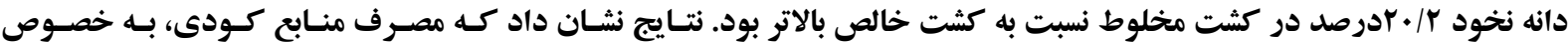

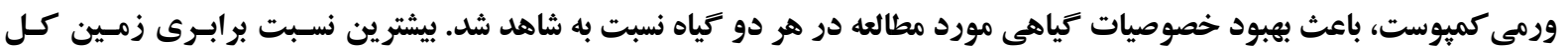

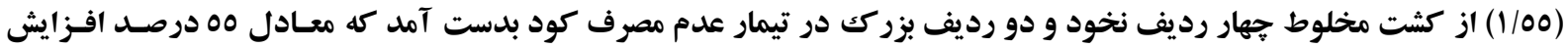

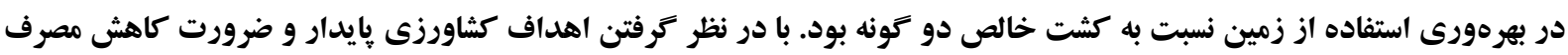

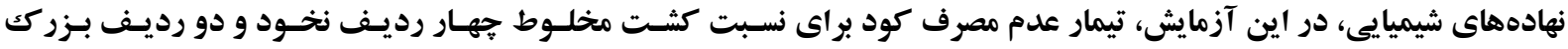


زيستى نشان داده شد كه كشت مخلوط ذرت و لوبيـا در تيمـار كـود زيسـتى، بيشـترين سـودمندى بدســ آمـــ

.(Dabbagh Mohammadi Nassab et al., 2015) استفاده طولانى مـدت از كودهـاى شـيميايى باعث

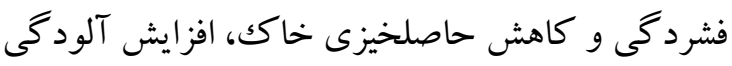

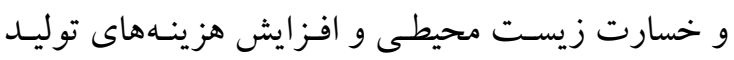

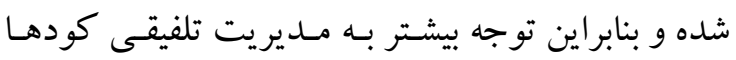
معطوف شـده اسـت (Nassiri Mahallati et al., 2001). كودهاى زيستى داراى جمعيت متراكمسى از موجـودات

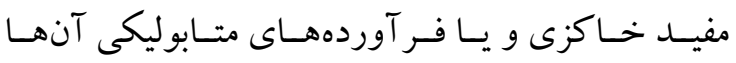

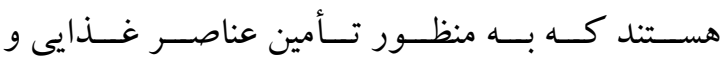

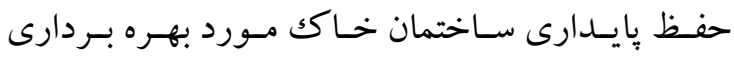

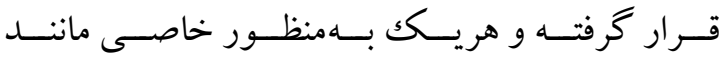
تثبــت نيتــروزن و رهاســازى يــونهــاى فســفات، يتاسيم و آهن از تركيبات نامحلول آنها توليـد مى شئسوند

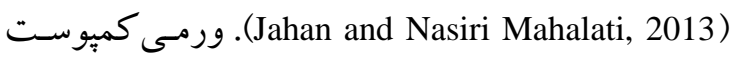
نوعى كـود آلى بيولوزيكى اسـت كـه از طريـق بهبـود

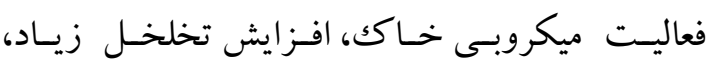

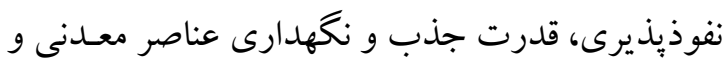

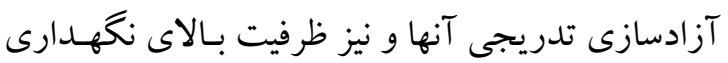

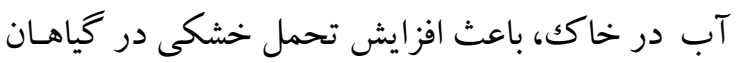

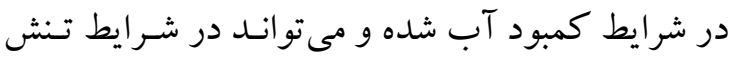
خشكى موثر باشــ (Tohidinejad et al., 2011). بـهنظـ مىرسد كه با بهره گيرى از كودهاى زيستى و آلى در

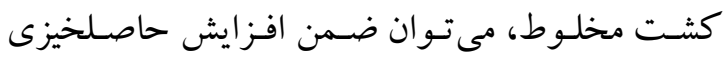

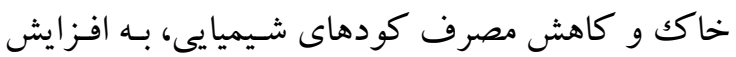

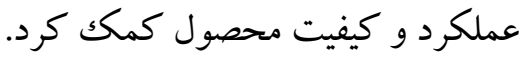
با توجـه بـه مشككلات خشكك شـدن بخـش زيــادى

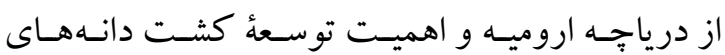
روغنى و گسترش برنامههاى تحقيقـات در بـاره كياهـان

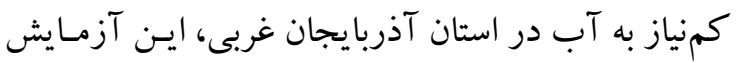

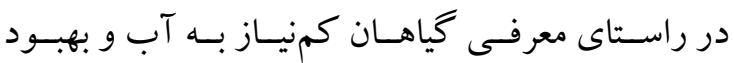
الخوى كشت در راستاى كشـاورزى بايسـار اجـرا شـد.

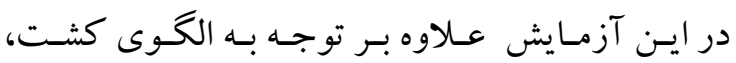

\section{مقلدمه}

افزايش تقاضا براى روغـنهـاى نبـاتى در بازارهـاى

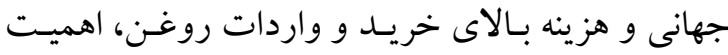

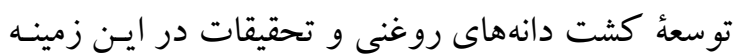

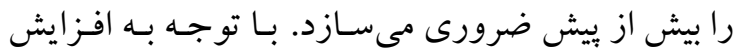

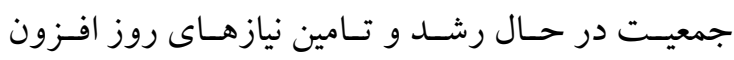

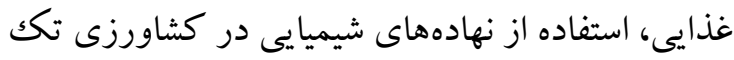

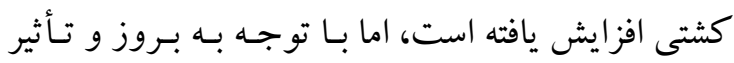

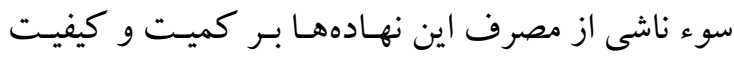

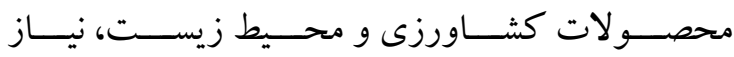

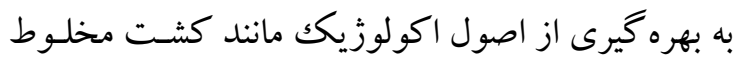

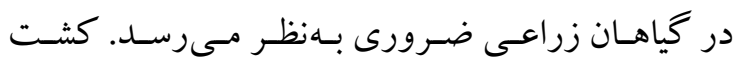

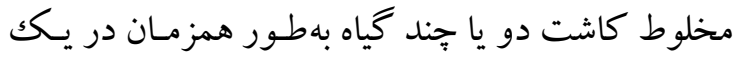

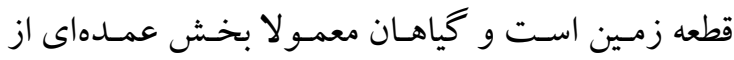

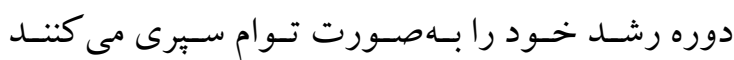

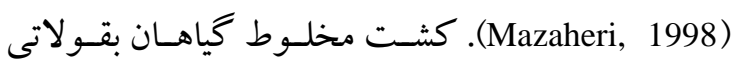
با ساير كياهان، متداول ترين نوع كشت مخلوط بهشـمار مسىرود. در ارزيـابى زراعى، اكولـوزيكى و اقتصـادى

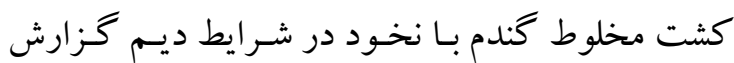

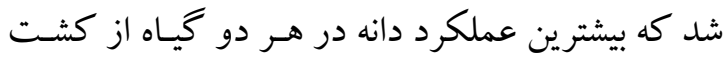
خالص آنها بـهدست آمـد (Javanmard et al., 2016). نتيجه يكك آزمايش ديخر نشان داد كه عملكرد دانسه و اجززاى عمكــد در كشـت مخلموط سـياهدانه و نخـود،

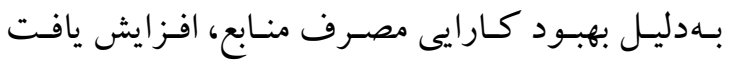
(Gholinezhad and Rezaei-Chiyaneh, 2014) آزمايش در كشت مخلوط باقلا و بادرشبى ززارش شـد

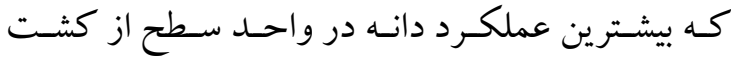
خالص باقلا بهدست آمده و تيمار كود شيميايى عملكرد

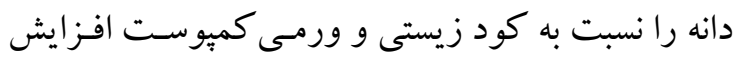

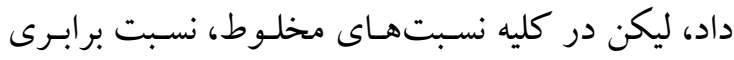

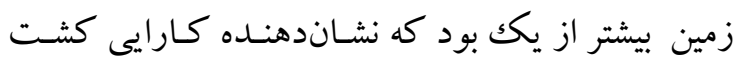

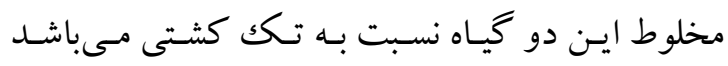
(Vafadar-Yengeje et al., 2017)

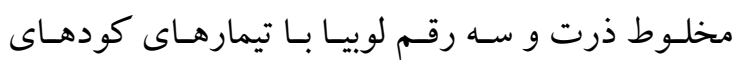


بلو ككهاى كامل تصادفى با سـه تكـرار در سـال زراعى 99- هوبا در مزرعسهاى واقـع در اسـتان آذربايجـان

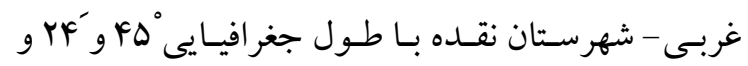
عرض جغرافيايى ${ }^{\circ}$

$$
\text { دريا اجرا شد. }
$$

تيمارهاى آزمـايش شـامل الكَوى كاشـت در شـش

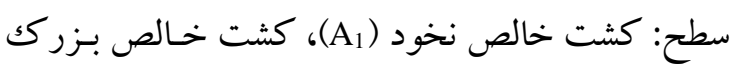

اثـر مصـرف كـودهـاى زيستى، آلى و شـيميايى بـر

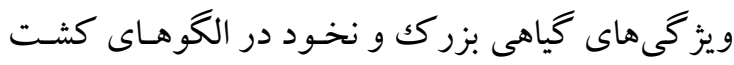

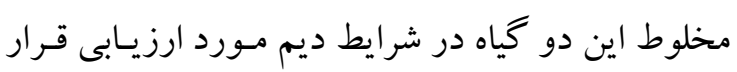
كرفت. - مخوط

\section{مواد و روشها}

اين آزمايش بـهـورت فاكتوريـل در قالب طـرح

جدول ا-ميانگين بارندگى، درجه حرارت و رطوبت نسبى هوا شهرستان نقده در سال 99-هه؟1

Table 1. Average rainfall, temperature and relative humidity of Naqadeh, Iran (2016)

\begin{tabular}{|c|c|c|c|c|c|c|c|c|c|c|c|}
\hline & & $\begin{array}{l}\text { مep. } \\
\text { Sep. }\end{array}$ & $\begin{array}{c}\text { آبان } \\
\text { Oct. }\end{array}$ & $\begin{array}{c}\text { آذر } \\
\text { Nov. }\end{array}$ & $\begin{array}{c}\text { s } \\
\text { Dec. }\end{array}$ & $\begin{array}{l}\text { بهمن. } \\
\text { Jan. }\end{array}$ & $\begin{array}{c}\text { اسفند. } \\
\text { Feb. }\end{array}$ & $\begin{array}{l}\text { فروردين } \\
\text { Mar. }\end{array}$ & $\begin{array}{c}\text { ارديبهشت } \\
\text { Apr. }\end{array}$ & $\begin{array}{l}\text { خرداد } \\
\text { May. }\end{array}$ & $\begin{array}{r}\text { تير. } \\
\text { Jun. }\end{array}$ \\
\hline Rainfall (mm) & بارندگى & 4.5 & 14.7 & 59 & 13.8 & 38.2 & 64.6 & 38.6 & 12 & 2.7 & 2.2 \\
\hline Temperature $\left(\mathrm{C}^{\circ}\right)$ & دما & 15.1 & 10 & -1.6 & -4.7 & -2.7 & 3.6 & 10.7 & 22.5 & 20.2 & 24.5 \\
\hline $\mathrm{RH}(\%)$ & رطوبت & 57.6 & 69.3 & 71.5 & 85.1 & 82.6 & 73.4 & 64.2 & 59.4 & 51.8 & 56 \\
\hline
\end{tabular}

(A6)

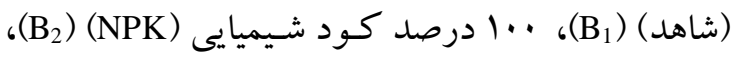

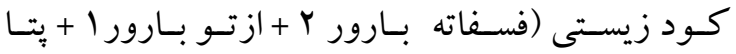

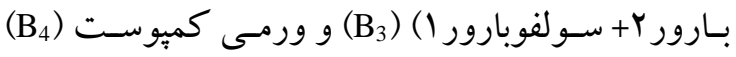

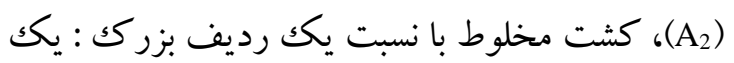

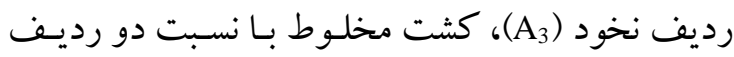

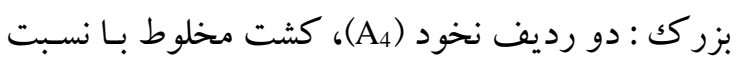

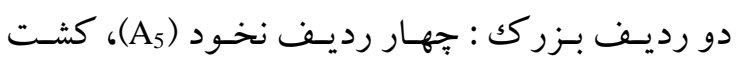

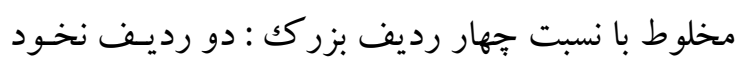

جدول r - خصو صيات فيزيكى و شيميايى خاكك مزرعه آزمايشى و ورمى كميوست

Table 2. Physical and chemical properties of the soil of experiment site and vermicopost

\begin{tabular}{|c|c|c|c|c|c|c|c|}
\hline & $\begin{array}{c}\text { بافت } \\
\text { Texture } \\
\end{array}$ & 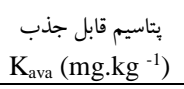 & 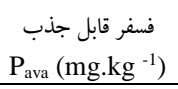 & $\begin{array}{c}\text { نيتروزن كل } \\
\text { Total N (\%) } \\
\end{array}$ & $\begin{array}{c}\text { موادآلى } \\
\text { Organic matter }(\%)\end{array}$ & $\begin{array}{l}\text { هدايت الكتريكى } \\
\left(\mathrm{dS} . \mathrm{m}^{-1}\right)\end{array}$ & $\begin{array}{l}\text { اسيديته } \\
(\mathrm{pH}) \\
\end{array}$ \\
\hline $\begin{array}{l}\text { خاك } \\
\text { Soil }\end{array}$ & $\begin{array}{c}\text { رس سيلتى } \\
\text { Silty- Clay }\end{array}$ & 242 & 11.7 & 0.09 & 1.09 & 0.52 & 7.75 \\
\hline $\begin{array}{l}\text { ورمى كميوست } \\
\text { Vericompost }\end{array}$ & - & 2.61 & 3.10 & 3.82 & 8.69 & 4.08 & 8.15 \\
\hline
\end{tabular}

بذر هر دو كياه يك ساعت قبل از كشت با كود زيستى فسفاته بارور Y (حاوى دو نوع باكترى حل كننده فسفات:

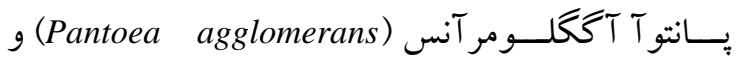
سـودوموناس يوتيـا (Pseudomonas putida) بـا تعـداد 9. اباكترى زنده و فعال در هر كرم كـود بيولوزيكـك)،

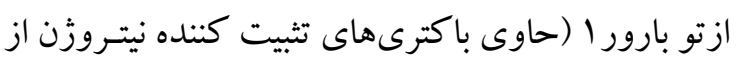

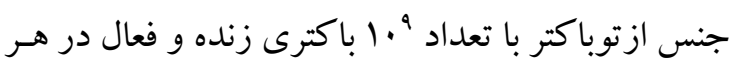

براى تيمار ․ أدرصد كود شيميايى كوددهى بـر

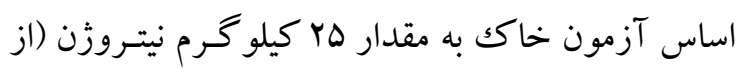

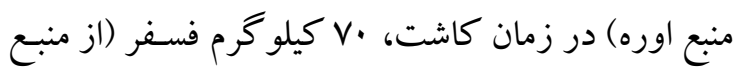

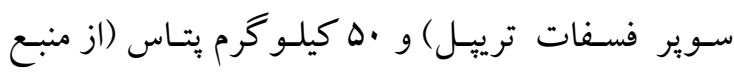

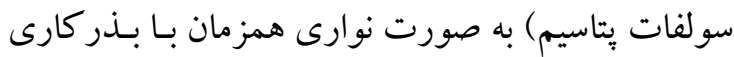

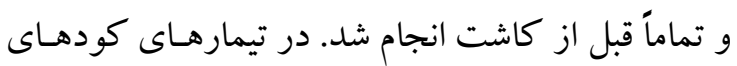
زيستى و آلى از هيج نـوع كـود شـيميايى استفاده نشـد. 
در مرحلة كلدهى بوتههاى نخـود، جهـت شـمارش تعداد كرههاى ريزوبيومى ابتدا ينج بوته بـا ريشـه كامـل از عمـق •له سـانتيمترى خـاكك بـا بيـل برداشـت و و يسس از شستشـو بــا آب مقطـر، ريشـههــا در

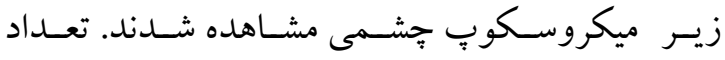
كـرههـاى روى ريشـههـاى هـر بوتسه كـه شـامل

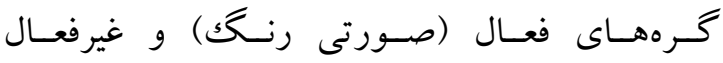

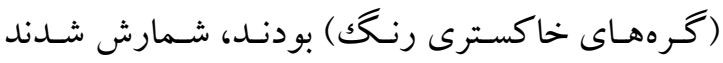

.(Liu et al, 2017; Tadayyon and Ghorbaninejad, 2012) در بايـان فصـل رشـد، جهـت محاسـبه عملكـرد دانسه و عملكرد بيولوزيكك، برداشت بوتهها با رعايت اثر حاشيه از مسـاحت شـش متـر مربـع از هـر كـرت انجـام شــــ.

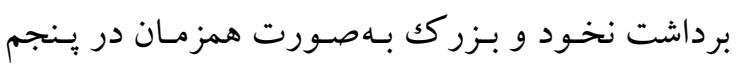

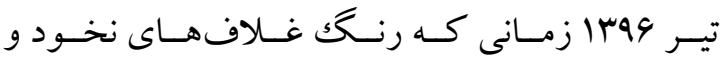

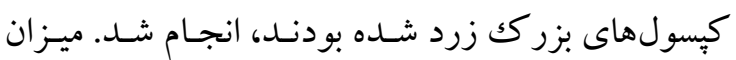
يرو تئين دانه نخود بر اساس ميزان نيتروزن دانه با استفاده

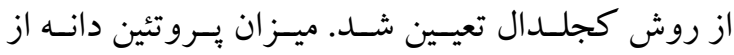

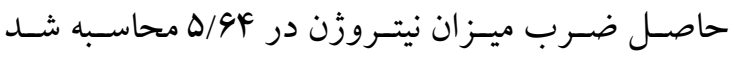
(Sosulski and Holt, 1980) ميز ان روغن بزرك نيز بـا

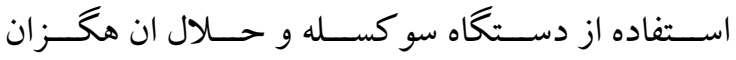
انسدازهگ گيرى شــ (Rezaei-Chiyaneh et al., 2015). عملكرد روغن از حاصل ضرب عملكـرد دانسه و درصـد روغن محاسبه شد. براى ارزيابى كشت مخلوط نخـود و بزركك در مقايسه بـا كشـت خـالص، از شـاخص نسـبت برابرى زمين (Land Equivalent Ratio; LER) (بر اساس عملكرد دانه) (رابطه ()) استفاده شد (Mazaheri, 1998): $\mathrm{LER}=\frac{\mathrm{Y}_{1}}{\mathrm{~F}_{1}}+\frac{\mathrm{Y}_{2}}{\mathrm{~S}_{2}}$

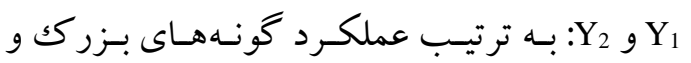
نخود در مخلوط و F1 و S2: عملكرد بزر كك و نخـود در كشت خالص هستند. جهت تجزيـه دادههـا از نـرم افززار 9.4 SAS و بـراى مقايسه ميانكين ها از آزمون LSD در سطح احتمـال يـنج درصد استفاده شد.
كرم كود بيولوزيك) و يتا بارور ب (حاوى بـاكترىهـاى

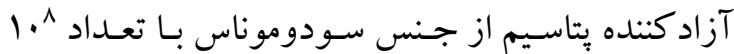
باكترى زنده و فعال در هر گرم كود بيولوزيك)، هرسه

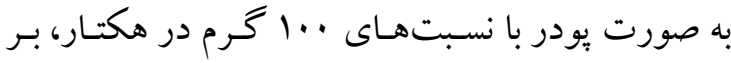
اساس دستور العمل توصيه شده توسط شـركت زيست فنـاور سـبز، تلقـيح شــند. بـراى تيمـار كـود زيسـتى از سولفوبارور ا (حاوى باكترى تيوباسيلوس بـا تعـداد ^•1

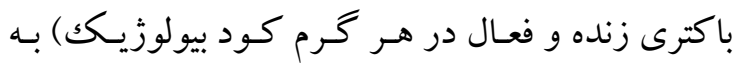
صورت يودر به ميزان V كيلو گرم در هكتار استفاده شد. براى اطمينان از اثربخشى آن سه هفته قبل از كاشـت بـهـ

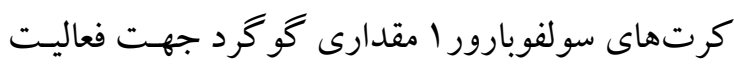
باكترهاى اين كودها اضافه و با خاكك مخلـوط كرديـد. كود ورمى كميوست نيز قبل از كاشت بـه ميـزان · ا تـن در هكتـار در تيمارهـاى مـورد نظـر بـهــور يكنو اخـت يخش و با خاكك مخلوط شد. فواصل بـين رديـف بـراى هر دو كياه •له سانتيمتر و طول رديف ها جهار متـر بـود. بذرهاى بزركك به فاصله سه سانتيمتر و بذرهاى نخود بـه فاصله هشـت سـانتى متـر روى رديـف هـا در تـاريخ اسفند ماه سال هوبا بهصسورت جـوى و يشـته، بـهـور همز مان كشت شـدند. تـراكم نهايى در كشـت خـالص براى نخود و بزركك بهترتيـب له و 94/94بوتـه در متـر مربـع بـود. بــرهاى نخـود قبـل از كاشـت بـا بـاكترى ريزوبيوم لكومينـوزاروم (Rhizobium leguminosarum) آغشته شدند كه از سازمان تحقيقات آب و خاكك كرج

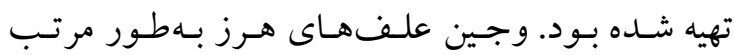
بـهـورت دسـتى انجـام شــــ نخـود مـورد اسـتفاده از تودههاى بومى شهرستان نقده با مشخصات؛ ارتفاع بو تـه

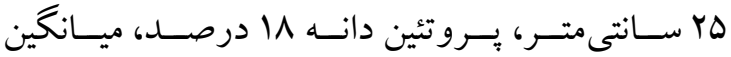

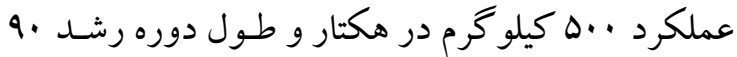

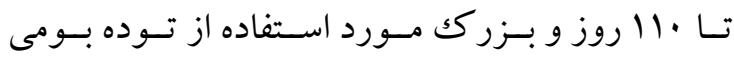
شاهين دز با مشخصات؛ ار تفاع بوته Y تا · F سانتى متر،

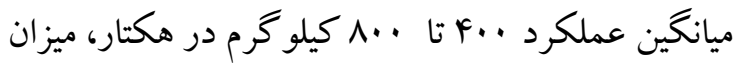
روغن دانه ·س تا ·F درصد و طول دوره رشد آن ·11 تا

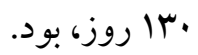


منابع بهدست آمد. بر اين اساس گزارش شد زمانى كـه

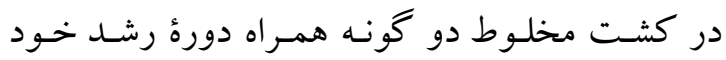

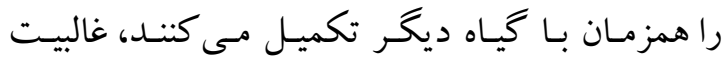

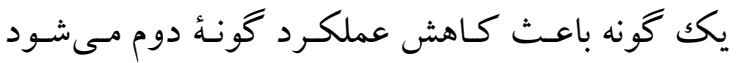
Rezaei-Chiyaneh et al., 2015) مخلوط نخود و زيره سبز ززارش شد كه عملكـرد دانـه نخود در كشت مخلوط نسبت به كشت خـالص كـاهش ونش داشت (Zarifpour et al., 2014). در تحقيـق ديخـرى نئس

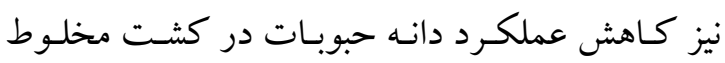

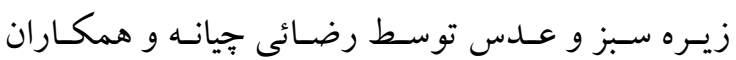
(Rezaei-Chiyaneh et al., 2014) هيريا (Hirpa, 2014) و كندم و نخود توسط جـو انمرد و همكاران (Javanmard et al., 2016) گزارش شده است. نتـايج مقايسـه ميانكين هــا نشــان داد كــه تيمــار

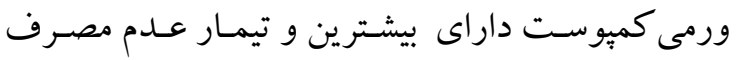
كود داراى كمترين عملكرد دانه و عملكـرد بيولوزيـك ونك بودند (جدول ؟). در اين تحقيق به نظـر مىرســ كـه در

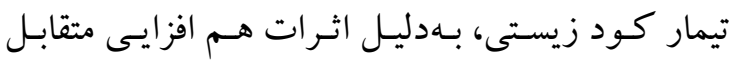

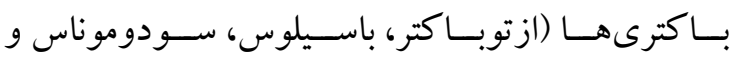

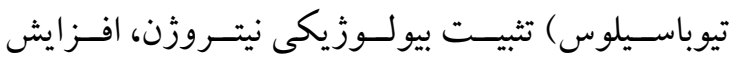

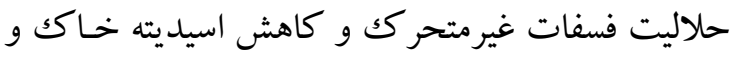
توليد انواع هورمونها و مواد محر كك رشد (سيتو كينين،

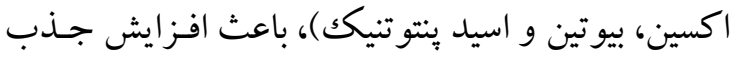

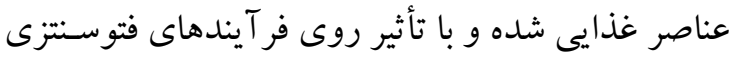

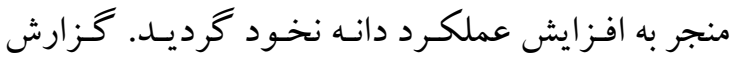
شده است كه ورمى كمبوست از طريق افزايش ظرفيـت نحهدارى رطوبت در خاكك باعث تحمل به خشكى بـ بـالا

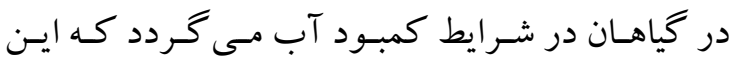

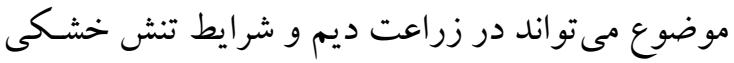

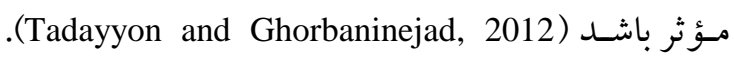

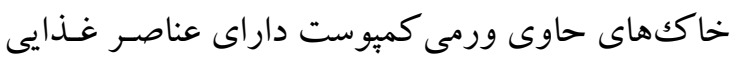
زيادى به ويزه نيتروزن، فسفر، كلسيم، بيتاسـيم و عناصـ

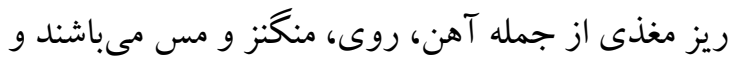

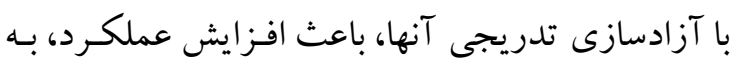

\section{نتايج و بحث}

صفات تياهى نخود نتـايج تجزيـه واريـانس نشـان داد كـهـ نسـبتهاى

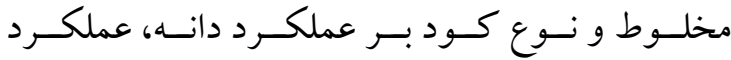
بيولوزيكك، تعداد كرههاى ريشـه و ميـزان يـروتئين دانه

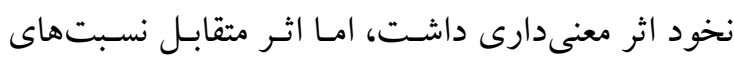

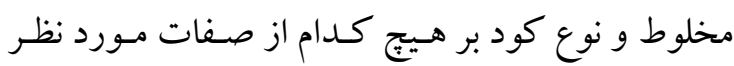

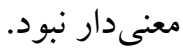

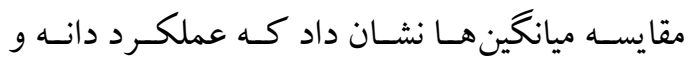
عملكرد بيولوزيك تحت تاثير نسبت هاى مخلموط قرار

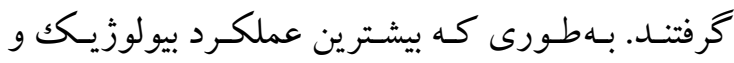

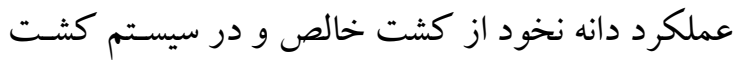
مخلوط، كمترين عملكرد بيولوزيكك و عملكرد دانسه از

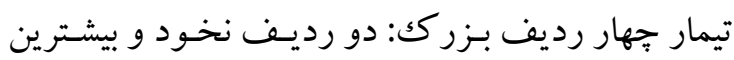

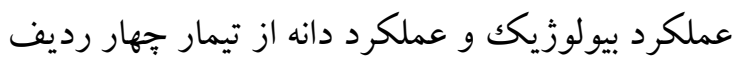

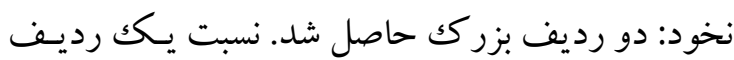

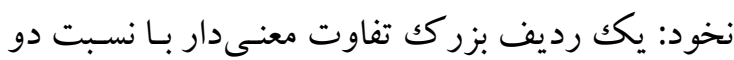
رديف نخود: دو رديف بزرك نداشت (جدول س). عملكرد دانه نخود در نسبتهاى مخلوط درد مقد مقايسـهـ

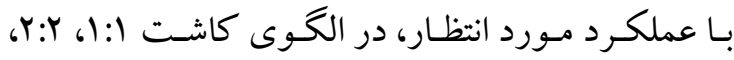

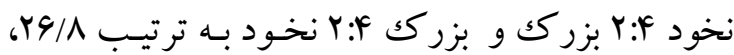

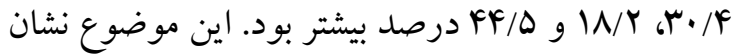

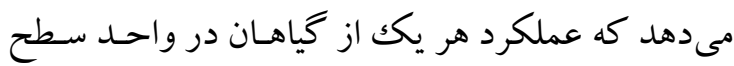
يكسان بيشتر از كشت خالص آنها بـوده و نشـان دهنـده برترى كشت مخلوط بـر كشـت خـالص اسـت. بـه نظر

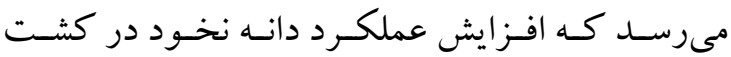
مخلوط نسبت به عملكرد مورد انتظار، بـه دليل استفاده

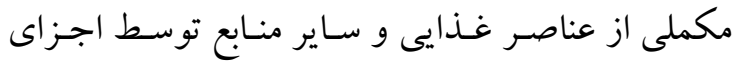

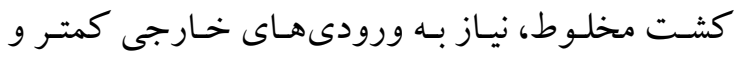

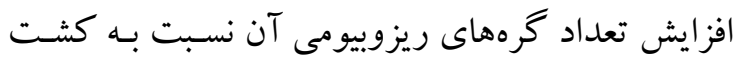

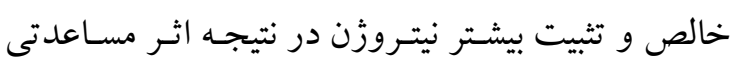

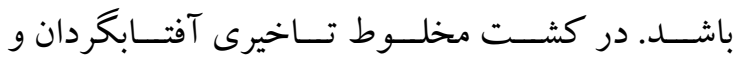
باقلا مشخص شد كه بيشترين عملكـرد بـاقلا از كشـت التح

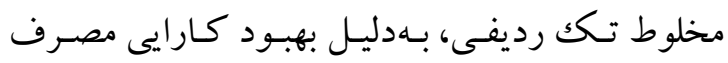


جدول r - مقايسه ميانخين اثر تيمارهاى كشت مخلوط و نوع كود بر خصوصيات گياهى نخود

Table 3. Mean comparison of plant characteristics of chickpea in intercropping and fertilizer source treatments

\begin{tabular}{|c|c|c|c|c|c|}
\hline $\begin{array}{c}\text { تيمارهاى آزمايشى } \\
\text { Treatments }\end{array}$ & & & & & \\
\hline $\begin{array}{c}\text { نسبتهاى مخلوط } \\
\text { Intercropping ratios }\end{array}$ & $\begin{array}{c}\text { عملكرد بيولوزيك } \\
\text { Biological yield } \\
\left(\mathrm{kg}^{\prime} \mathrm{ha}^{-1}\right)\end{array}$ & $\begin{array}{c}\text { عملكرد دانه } \\
\text { Seed yield } \\
\left(\mathrm{kg} \cdot \mathrm{ha}^{-1}\right)\end{array}$ & $\begin{array}{c}\text { عملكرد دانه مورد انتظار } 2 \text { عected seed yield (kg.ha-1) } \\
\text { Expected }\end{array}$ & $\begin{array}{l}\text { تعداد گرههاى ريزوبيومى } \\
\text { No. of rhizobium nodules }\end{array}$ & $\begin{array}{c}\text { Protein content of seed (\%) } \\
\text { Prتئين دانه }\end{array}$ \\
\hline Sole cropping & $1798 \mathrm{a}$ & $629 \mathrm{a}$ & 629.0 & $28.5 \mathrm{~d}$ & $15.3 \mathrm{~d}$ \\
\hline 1 row chickpea : 1 row linseed مخلوط يك رديف نخود: يكك رديف بزركك & $1303 \mathrm{c}$ & $430 \mathrm{c}$ & 314.5 & $38.3 \mathrm{a}$ & $19.8 \mathrm{a}$ \\
\hline 2 rows chickpea : 2 rows linseed مخلوط دو رديف نخود: دو رديف بزركك & $1395 \mathrm{c}$ & $452 \mathrm{c}$ & 314.5 & $34.6 \mathrm{~b}$ & $18.5 b$ \\
\hline 4 rows chickpea : 2 rows linseed مخلوط جهار رديف نخود: دو رديف بزركك & $1527 \mathrm{~b}$ & $513 b$ & 419.3 & $34.0 \mathrm{~b}$ & $17.9 \mathrm{bc}$ \\
\hline 2 rows chickpea : 4 rows linseed مخلوط جهار رديف بزرك: دو رديف نخود & $1160 \mathrm{~d}$ & $377 \mathrm{~d}$ & 209.6 & $31.2 \mathrm{c}$ & $17.4 \mathrm{c}$ \\
\hline $\begin{array}{c}\text { منابع كود } \\
\text { Fertilizer source } \\
\end{array}$ & $\begin{array}{c}\text { عملكرد بيولوزيك } \\
\text { Biological yield } \\
\left(\mathrm{kg}^{2} \mathrm{ha}^{-1}\right)\end{array}$ & $\begin{array}{c}\text { عeed yield } \\
\text { Sملكرد دانه } \\
\left(\mathrm{kg} \cdot \mathrm{ha}^{-1}\right) \\
\end{array}$ & & $\begin{array}{c}\text { تعداد گرههاى ريزوبيومى } \\
\text { No. of rhizobium nodules }\end{array}$ & $\begin{array}{c}\text { بروتئين دانه } \\
\text { Protein content of seed (\%) } \\
\end{array}$ \\
\hline Without fertilizer & $126 \mathrm{c}$ & $439 \mathrm{c}$ & & $29.7 \mathrm{c}$ & $16.3 \mathrm{c}$ \\
\hline Biofertilizers & $1403 b$ & $478 b$ & & $34.6 \mathrm{ab}$ & $18.1 \mathrm{~b}$ \\
\hline Vermicopost & $158 \mathrm{a}$ & $514 \mathrm{a}$ & & $36.2 \mathrm{a}$ & $18.9 \mathrm{a}$ \\
\hline Chemical fertilizer & $1492 \mathrm{ab}$ & $490 \mathrm{ab}$ & & $32.8 \mathrm{~b}$ & $17.8 \mathrm{~b}$ \\
\hline
\end{tabular}


ريشه افزايش يابــ. در تأييــ ايسن نتـايج افزايش تعـداد

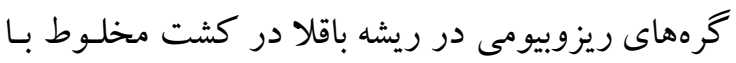

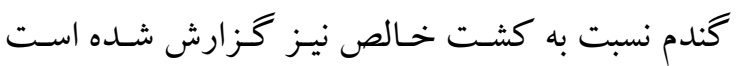

.(Liu et al., 2017)

نتــايج نشــان داد كــه بيشـترين تعـداد گرههــاى

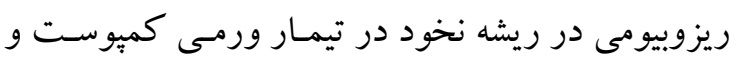

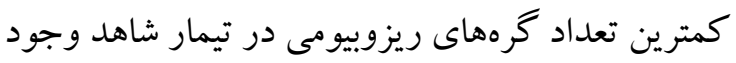

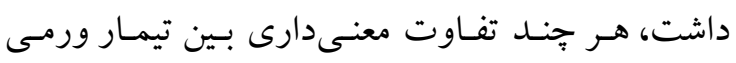

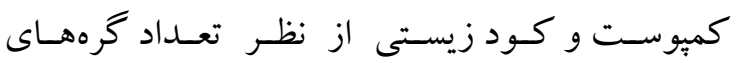

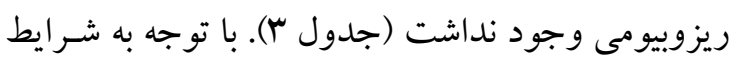

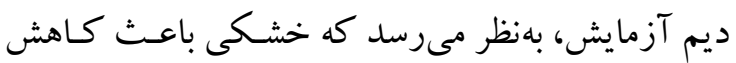
تعداد ريزوبيومهاى همزيست در ريشه گياهان مىشـود.

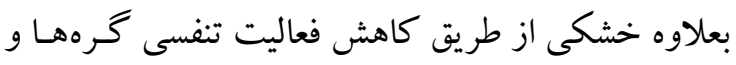

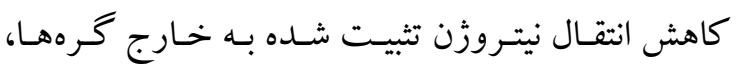

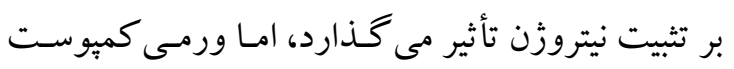

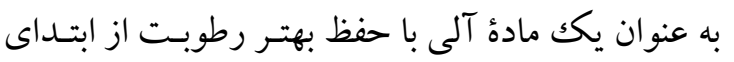

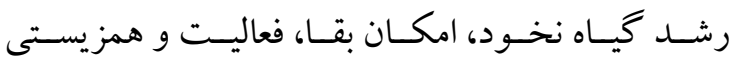

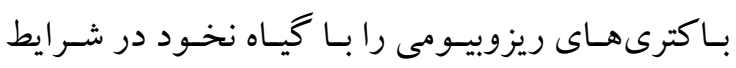

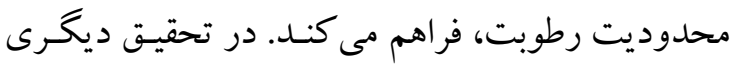

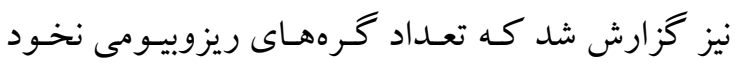

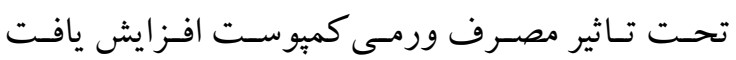

.(Tadayyon and Ghorbaninejad, 2012)

مقايسـه ميانگين هـا نشـان داد كـه بيشـترين ميـزان

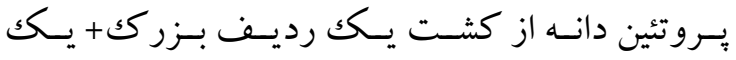
رديف نخود و كمترين ميزان آن از كشت خالص نخدود

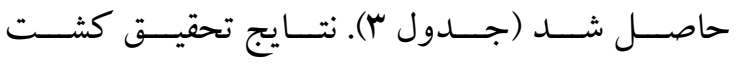

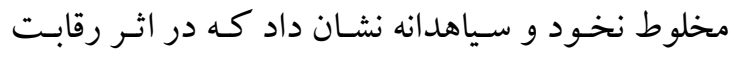

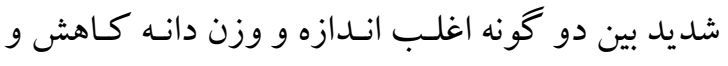

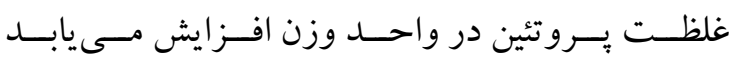

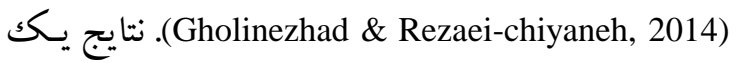
تحقيق نشان داد كه وقتى بقولات در كنار گونه ديخر به صورت مخلوط كشت مىشوند، بهدليل اثر مكملى جزء

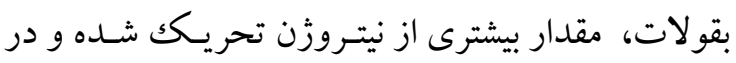

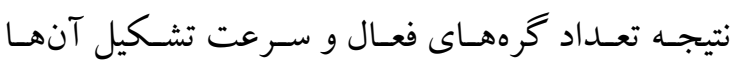

$$
\text { خصـــوص در شــــرايط كمبـــود آب، مىشــــوند }
$$
(Tohidinejad et al., 2011) (Tadayyon and Ghorbaninejad, 2012) كردند كه گياه نخـود، واكـنش خـوبى بـه كمبوست در

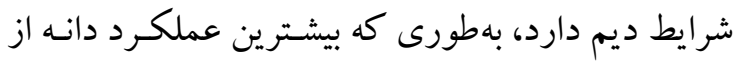

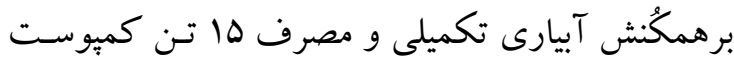

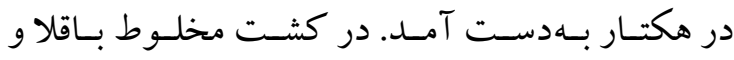

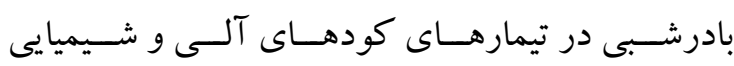

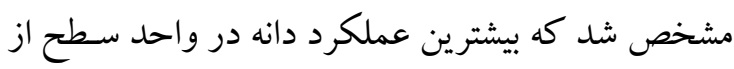

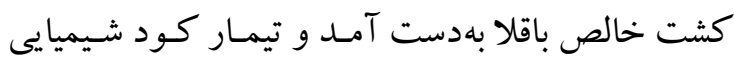

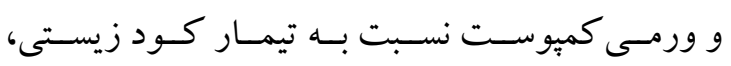

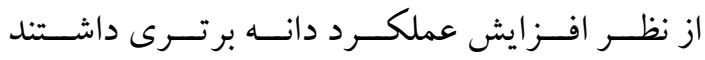
(Vafadar-Yengeje et al., 2017) شنبليله و زنيان در تيمارهاى كودهاى زيستى و شـيميايى

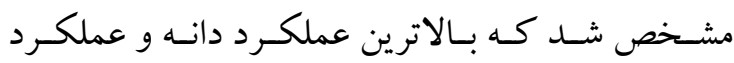
بيولوزيكك شنبليله بهترتيب در تيمارهاى كود شيميايى و

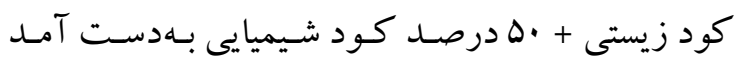
.(Rezaei-Chiyaneh et al., 2015) نتايج نشان داد كه نسبتهاى مخلوط اثر معنى دارى

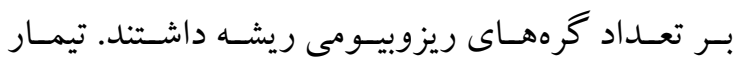

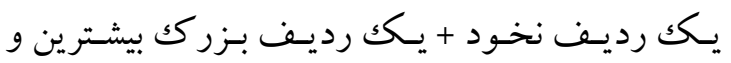

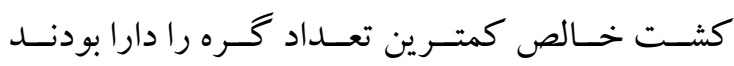

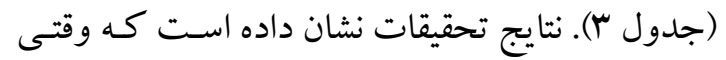

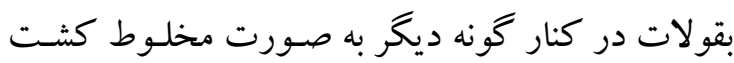

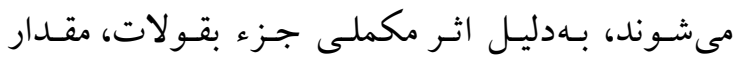
بيشترى از نيتروزن تحريكك شده و در نتيجه تعداد كره

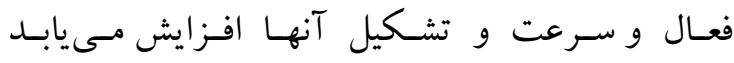
(Hauggard-Nielson et al., 2001). در تحقيق حاضـر نيز بهنظر مى رسد كه افزايش تعداد گره در ريشه نخود

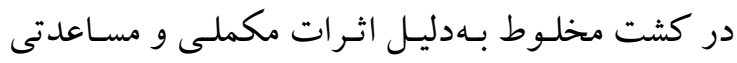

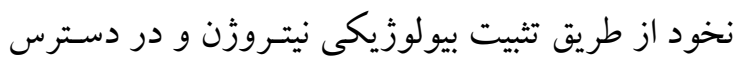

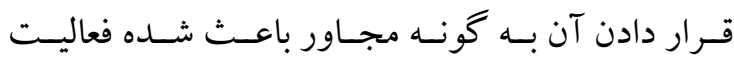

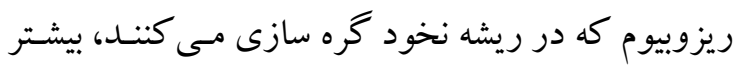

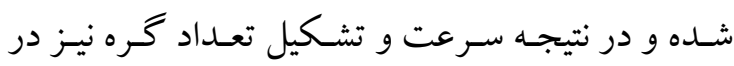


كاهش رقابت بين گونهاى براى منابع محيطى ذكر كرد

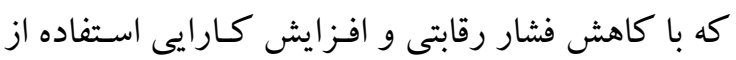

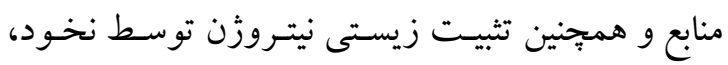

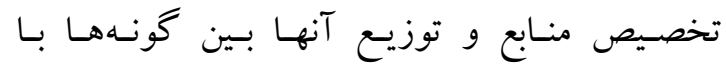

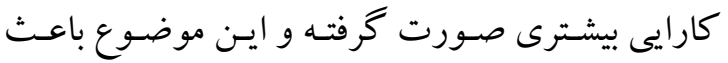

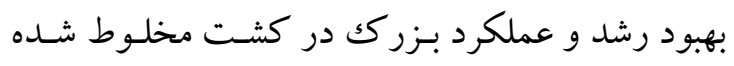
است. در كشـت مخلـوط زيـره سـبز و شـبليله گتزارش

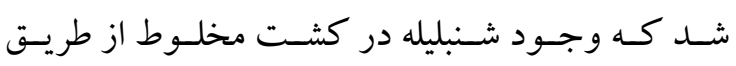

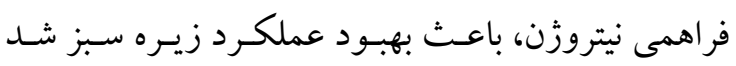
Rezvani Moghadam and Moradi, 2013) مخلوط نوارى كنـدم-كلـزا مشـخص شـد كـه بيشـترين

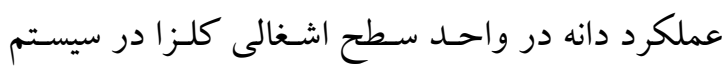

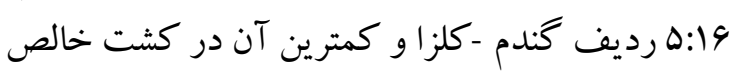
بهدست آمد (Amirmardfar et al, 2016). ايس محققـان

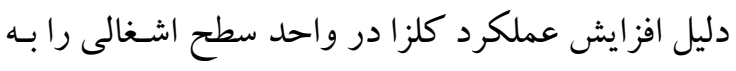
اصل توليد مساعدتى نسبت دادند. اصل توليد مسـاعدتى در كشتهاى مخلوط وقتى مطرح اسـت كـه كياهـان

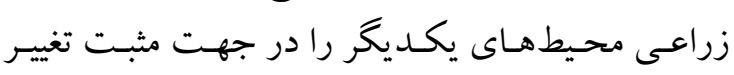

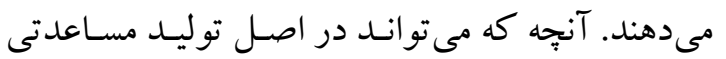
مطرح شود، تسهيل جذب عناصر غذايى، كاهش حملـه

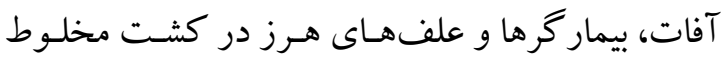
نسبت به كشتهاى خالص مىباشد.

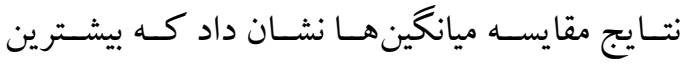
عملكرد بيولوزيـك و عملكـرد دانسه و كمترين مقـادير

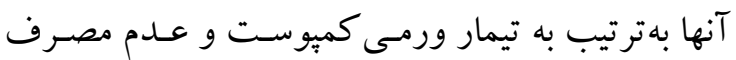

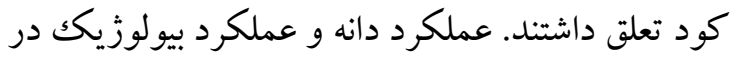
تيمار ورمى كميوست نسبت بـه تيمـار شـاهد بـه ترتيـب

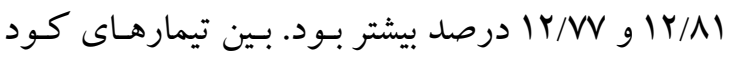

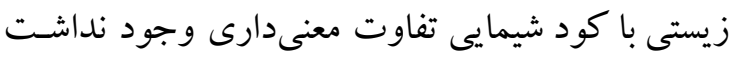

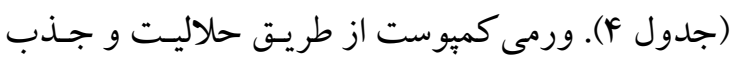

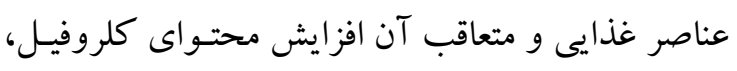

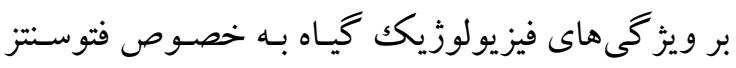

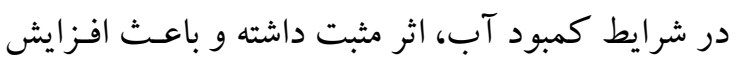

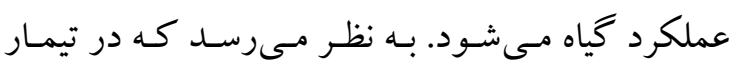

افزايش مىيابد و افزايش تثبيت نيتروزن حاصل از جـزء

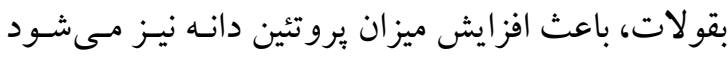

(Hauggard-Nielson et al., 2001) تيمار ورمى كميوست بيشترين بروتئين دانه و تيمـار

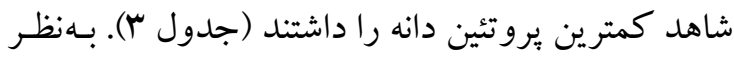

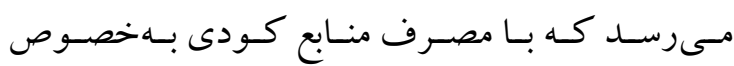
ورمى كمبوست در شرايط كمبود آب، تعداد گرههـاى

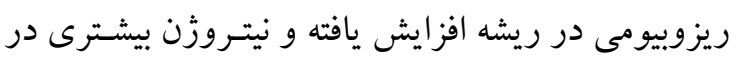

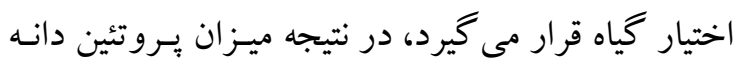

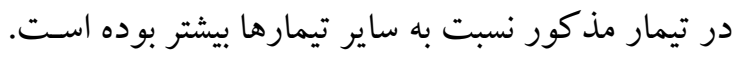

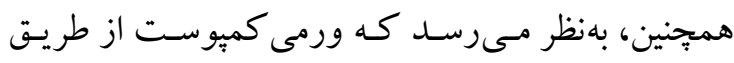

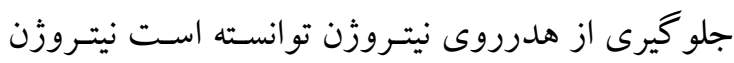

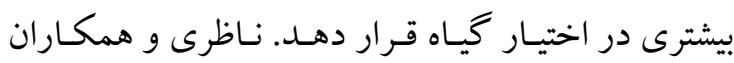
(Nazeri et al, 2010) در تيمـار كـود زيسـتى + •هدرصسـ كــود شــيميايى، بيشترين ميزان بروتئين دانه را توليد كرد. صفات كياهى بزر كى نتايج حاصل از تجزيه واريانس دادهها نشـان داد كـهـ

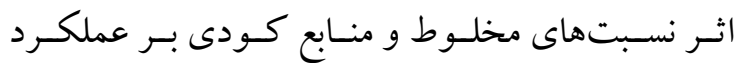

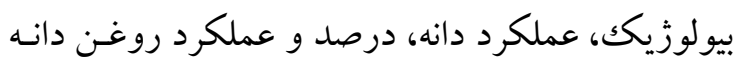

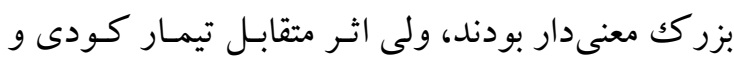

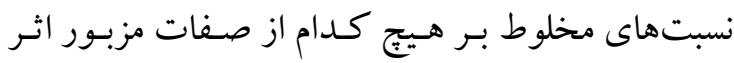

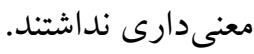
مقايسه ميـانگين هـا نشـان داد كـه بيشترين عملكـرد

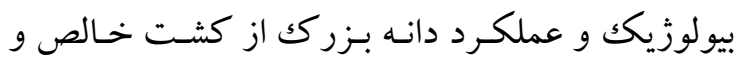

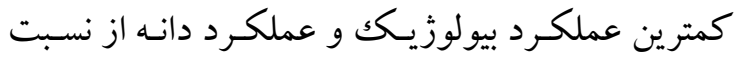

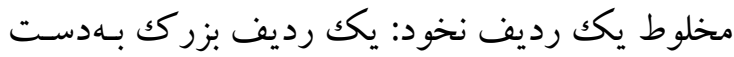

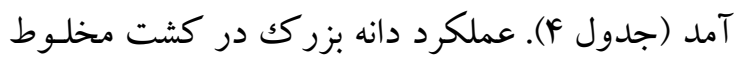

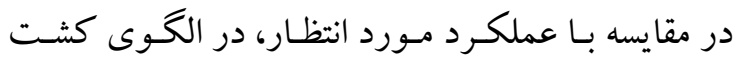

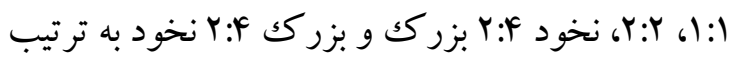

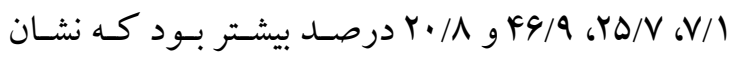
دهنده مزيت كشت مخلموط بـزر كك بـا نخـود در واحــ سطح يكسان مىباشد. افزايش عملكرد در كشت مخلوط را مىتوان بهدليل 


$$
\text { جدول F - مقايسه ميانكين اثر تيمارهاى كشت مخلوط و نوع كود بر خصوصيات گياهى بزر كى }
$$

Table 4. Means comparison of plant characteristics of linseed in intercropping and fertilizer source treatments

\begin{tabular}{|c|c|c|c|c|c|c|}
\hline $\begin{array}{c}\text { تيمارهاى آزمايشى } \\
\text { Treatments }\end{array}$ & & & & & & \\
\hline $\begin{array}{c}\text { نسبت هاى مخلوط } \\
\text { Intercropping ratios }\end{array}$ & $\begin{array}{c}\text { عملكرد بيولوزيكى } \\
\text { Biological yield } \\
\left(\mathrm{kg} \cdot \mathrm{ha}^{-1}\right)\end{array}$ & $\begin{array}{c}\text { عملكرد دانه } \\
\text { Seed yield } \\
\left(\mathrm{kg} \cdot \mathrm{ha}^{-1}\right)\end{array}$ & $\begin{array}{c}\text { عملكرد دانه مورد انتظار } \\
\text { Expected seed yield } \\
\left(k g . h^{-1}\right)\end{array}$ & $\begin{array}{c}\text { روغن دانه } \\
\text { Oil content of seed (\%) }\end{array}$ & $\begin{array}{c}\text { عملكرد روغن مورد انتظار } \\
\text { Expected oil yield } \\
\left(k g . h^{-1}\right)\end{array}$ & $\begin{array}{c}\text { عملكرد روغن } \\
\text { Oil yield } \\
\left(\mathrm{kg} \cdot \mathrm{ha}^{-1}\right) \\
\end{array}$ \\
\hline Sole cropping & $3571 \mathrm{a}$ & $945 \mathrm{a}$ & 945 & $34.35 \mathrm{~d}$ & 325.0 & $325 \mathrm{a}$ \\
\hline 1 row chickpea + 1 row linseed مخلوط يكك رديف نخود: يك رديف بزركك & $1975 d$ & $509 \mathrm{~d}$ & 472.5 & $37.70 \mathrm{a}$ & 162.5 & $192 d$ \\
\hline 2 rows chickpea : 2 rows linseed مخلوط دو رديف نخو د: دو رديف بزركى & $2492 \mathrm{c}$ & $636 c$ & 472.5 & $35.74 \mathrm{c}$ & 162.5 & $228 \mathrm{c}$ \\
\hline 4 rows chickpea : 2 rows linseed مخلوط جهار رديف نخود: دو رديف بزركى & $2345 \mathrm{c}$ & $594 \mathrm{c}$ & 315.0 & $36.18 b c$ & 108.3 & $220 \mathrm{c}$ \\
\hline 2 rows chickpea : 4 rows linseed مخلوط جهار رديف بزرك: دو رديف نخود & $3030 \mathrm{~b}$ & $796 b$ & 630.0 & $36.88 \mathrm{ab}$ & 216.6 & $289 \mathrm{~b}$ \\
\hline $\begin{array}{c}\text { منابع كود } \\
\text { Fertilizer source }\end{array}$ & $\begin{array}{c}\text { عملكرد بيولوزيك } \\
\text { Biological yield } \\
\left(\mathrm{kg}^{\prime} \mathrm{ha}^{-1}\right)\end{array}$ & $\begin{array}{c}\text { عملكرد دانه } \\
\text { Seed yield } \\
\left(\mathrm{kg} \cdot \mathrm{ha}^{-1}\right)\end{array}$ & & & $\begin{array}{c}\text { Oil content of seed (\%) } \\
\text { روغن دانه }\end{array}$ & $\begin{array}{c}\text { عملكرد روغن } \\
\text { Oil yield } \\
\left(\mathrm{kg} . \mathrm{ha}^{-1}\right)\end{array}$ \\
\hline Without Fertilizer & $2381 c$ & $603 c$ & & & $33.6 \mathrm{c}$ & $201 \mathrm{c}$ \\
\hline Biofertilizers & $2682 b$ & $700 \mathrm{~b}$ & & & $36.4 \mathrm{~b}$ & $253 b$ \\
\hline Vermicompost & $2958 \mathrm{a}$ & $794 a$ & & & $37.8 \mathrm{a}$ & $298 \mathrm{a}$ \\
\hline Chemical fertilizer & $2730 \mathrm{~b}$ & $692 b$ & & & $36.9 \mathrm{~b}$ & $254 \mathrm{~b}$ \\
\hline
\end{tabular}

Means in each column followed by similar letter(s) are not significantly different at 5\% probability level, using LSD test 
مقايسـه ميانكين هـا نشـان داد كـه كمترين عملكـرد

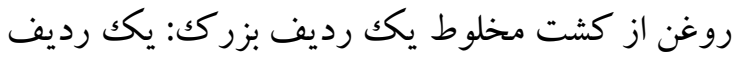

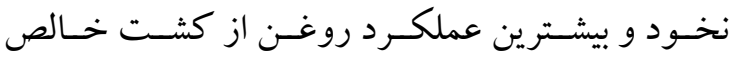

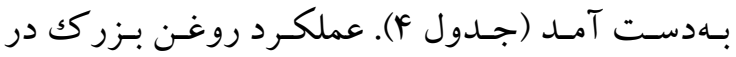
كشت مخلـوط در مقايسه بـا عملكـرد مـورد انتظـار در

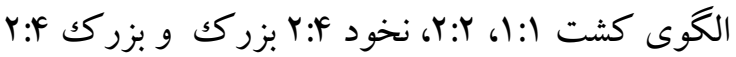

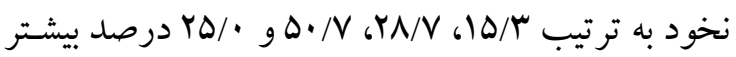

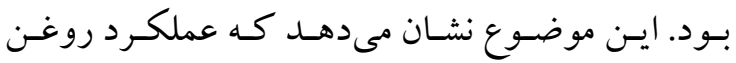

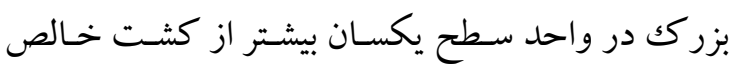

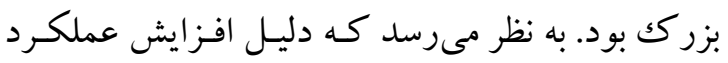
روغن بزركك در كشت مخلموط در مقايسـه بـا عملكـرد

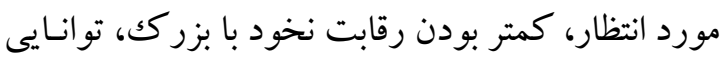

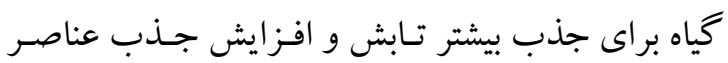

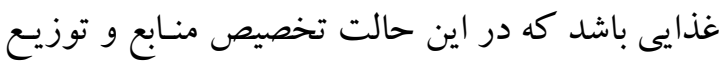
آنها بين گونهها با كارايى بيشترى صورت كر كرفته و ايـن

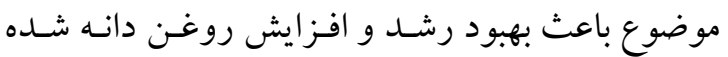

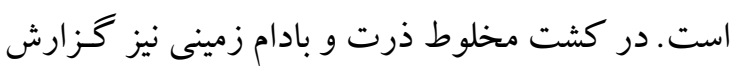

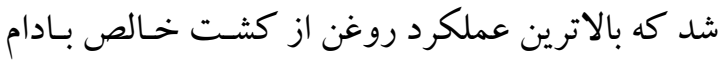
زمينى به دست آمد (Seyed noori et al, 2016). بـين منـابع كـودى نيـز تفـاوت معنى دارى از لحـاظ درصـد و عملكـرد روغـن دانـه مشـاهده شـــ. مقايسـهـ

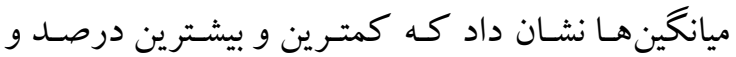
عملكـــد روغـن بـهـترتيـب مربـوط بـه تيمـار شـاهد

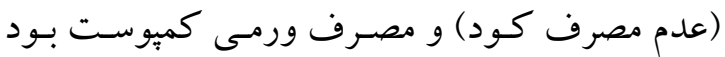

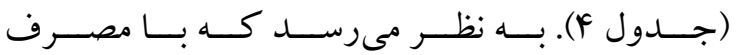
ورمسى كميوسـت، جـذب عناصـر غـذايى و تشـكيل

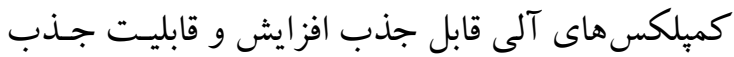

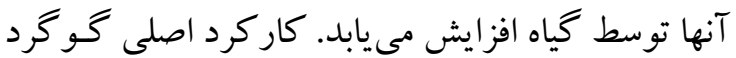
در كياهــان، كمــك بــه ســاخت اسـيدهاى آمينـــ

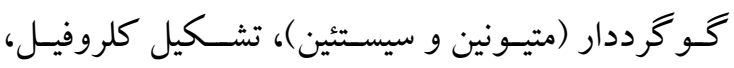

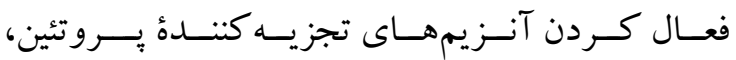

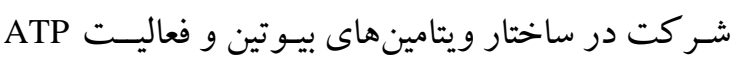

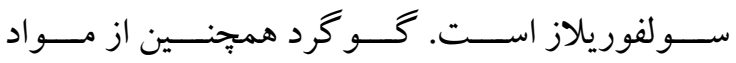

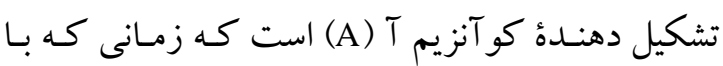

كود زيستى نيز ريزوباكترىهاى تحريك كنندهُ رشد بـا

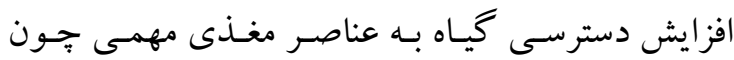

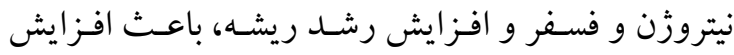

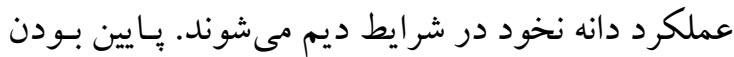

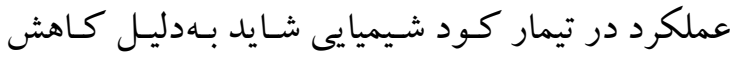

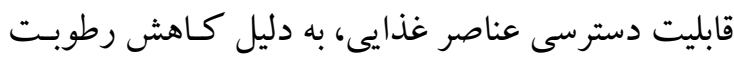

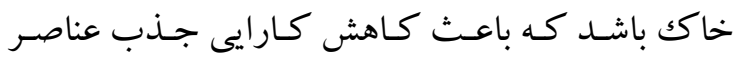
توسط ريشه هاى گياه نخود مى شود.

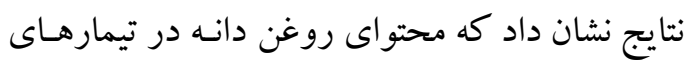
مخلوط بيشتر از كشت خالص بـود. كمتـرين و بيشترين

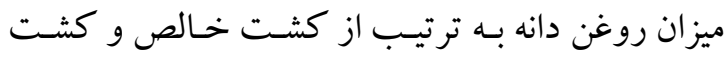
مخلوط يكك رديف بزركك: يكك رديـف نخـود حاصل

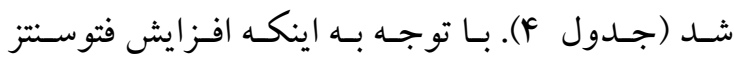

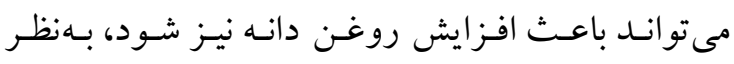

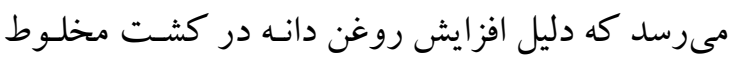

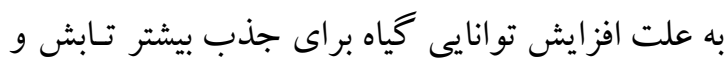

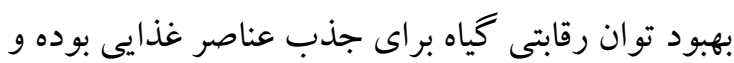
در اين حالت تخصيص منابع و توزيع آنها بين كونههـا

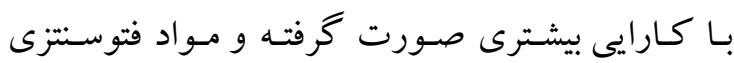

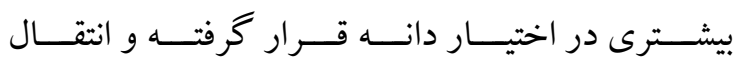

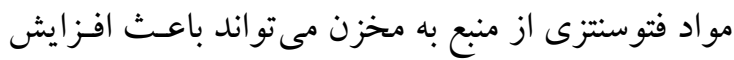

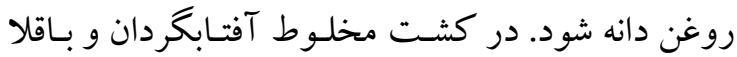
نيـز خزارش شـد كـه (Rezaei-chiyaneh et al, 2015) ميزان روغن دانه آفتابخر دان در كشت مخلموط بيشتر از كشت خالص بود. نتايج مقايسه ميانگين ها نشـان داد كـهـ

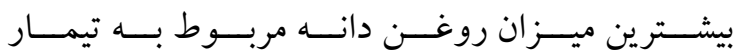
ورمى كمبيوست و كمترين ميزان روغـن بـه تيمـار شـاهد

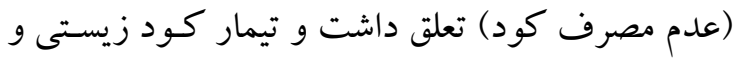

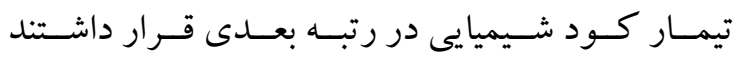
(جدول F). بهنظر مىرسد كه مصرف كودهـاى زيستى

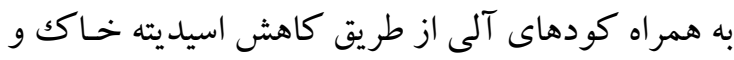

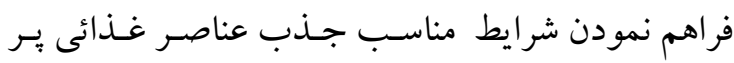

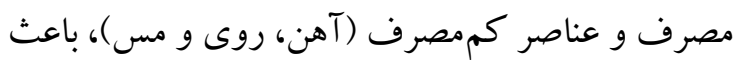
افزايش روغن دانه بزركى شدند. 
"اثر الكوى كاشت و منبع كود بر...، اسدى و همكاران، لهوا، .ب-19"

.(Heldt and Piechulla , 2013)

نتـايج نشـان داد كـه حسـاكثر نسـبت برابـرى زمسين

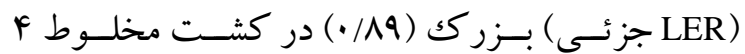

رديف بزرك : r ريف نخود در شـر ايط عـدم مصـرف كود و حداكثر LER جزئى نخود (A9/•) نيز در كشـت مخلوط r رديف بزركك : F رديف نخود در تيمار كود شيميايى بهدسـت آمـد. بـه طـور كلى، ميـانگين نسـبت برابـرى جزئسى بـزر كك نسـبت بـه نخـود بـالاتر بـود كـه مى توان جنين استنباط نمود كه بزرك از كشت مخلـوط با نخود اثر مثبت يذيرفته است (شكل ().
(A) اسيد استيكك تر كيب مسىشـود، اسـتيل كـو آنزيم آ

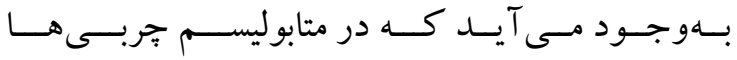
اهميت دارد. بهنظر مىرسد كه با اكسـايش گـو گرد در خـــاكك و توليـــد اســـيد ســـولفوريكك بــــا حضـــور بـاكترى تيوباسـيلوس، اسـيديته خــاكك كـاهش يافتـه و باعث انحلال و افزايش فعاليت و كارايى ساير باكترهاى موجود در تيمار كود زيستى شــده و قابـل جـذب شـــن

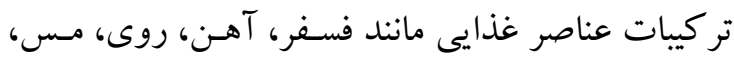

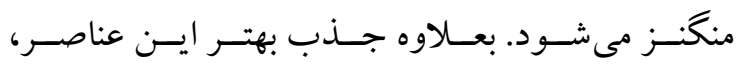
باعـث افـزايش ميـزان روغـن در دانسه بـزرك مى شــود

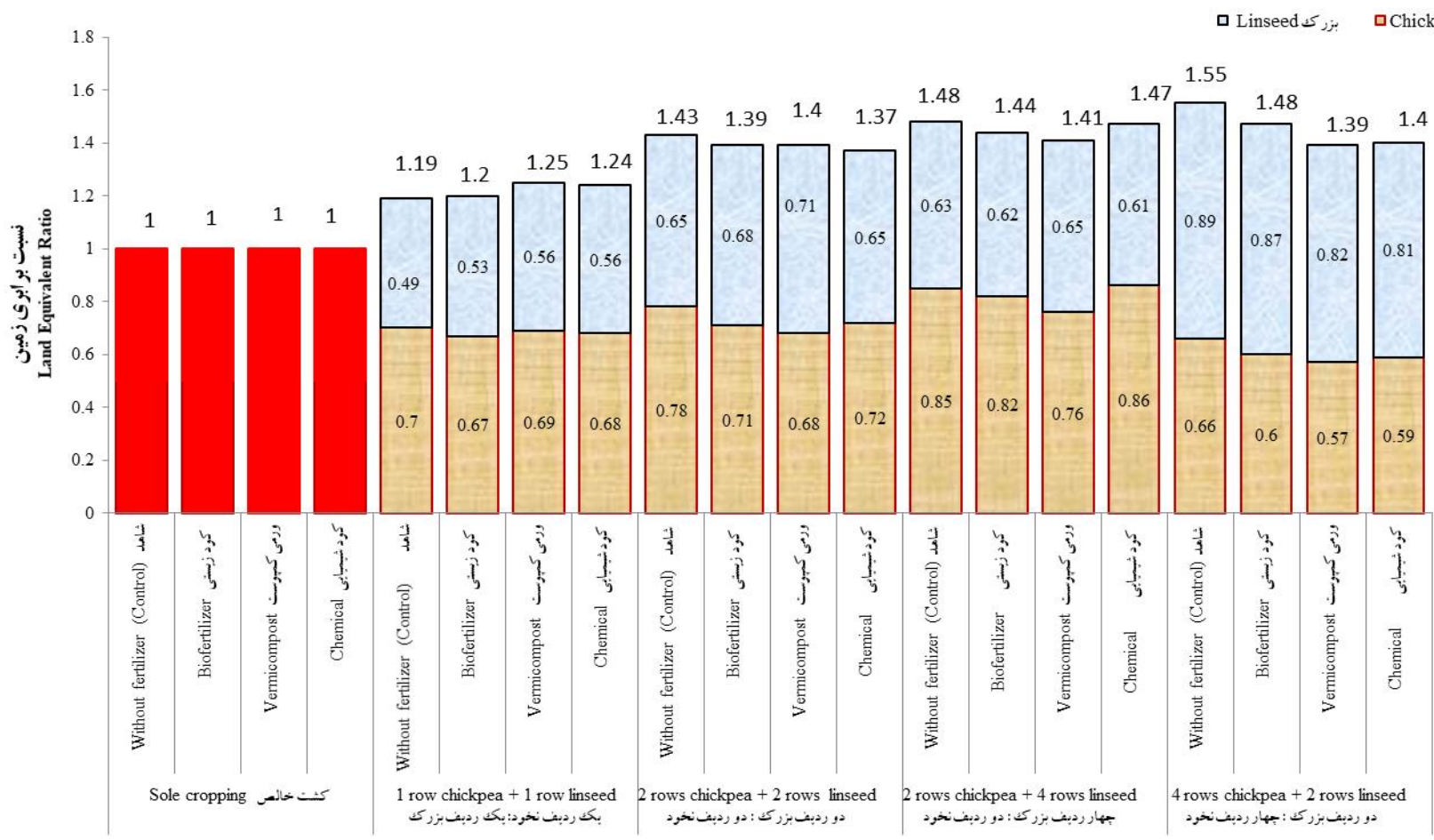

نسبتهاى مخلوط و تيمارهاى كودى

Intercropping ratios and fertilizer treatments

شكل 1- نسبت برابرى زمين كل براى عملكرد دانه بزركك و نخود در تيمارهاى نسبتهاى مخلوط و نوع كودى

Fig. 1. Land Equivalent Ratio (LER) for seed yields of linseed and chickpea in intercropping ratios and fertilizer source treatments

.(Gholinezhad \& Rezaei-Chiyaneh, 2014) نسبت برابرى زمين كل در تيمارهاى مخلوط بيشـتر از يكك بود كه نشان دهنده برترى كشت مخلـوط نسـبت بـه تكك كشتى در اين نسـبتهاى مخلـوط مسىباشـد. كشـت
محققــان ديخــرى در كشـت مخلــوط سـياهدانه

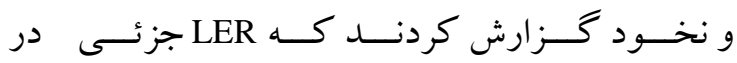
سـياهدانه بـالاتر از نخـود بـود و سـياهدانه از كشـت مخلـوط بـا نخـود اثـر مثبـت بيشـترى بذيرفتـه بـود 
كشت مخلـوط بـاقلا و بادرشبى در تيمارهـاى كودهـاى آلـى و شــيميايى (Vafadar-Yengeje et al., 2017)

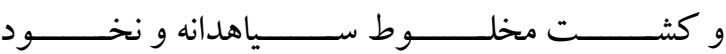
(Gholinezhad and Rezaei-Chiyaneh, 2014) نسبت هاى مخلوط، نسبت برابرى زمين بيشتر از يـكك بـود

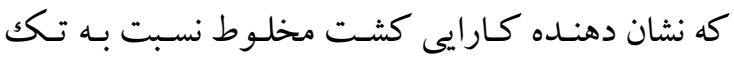
كشتى مىباشد.

\section{نتيجه Fيرى}

نتايج اين آزمايش نشان داد كه نسبتهاى مخلوط و نوع كود بـر خصوصسيات دو گيـاه بـزرك و نخـود اثر معنى دارى داشتند. بيشترين عملكرد دانه هر دو كونـه از كشت خالص آنها بهدست آمد، اما عملكرد هر يـكك از كياهان در واحد سطح يكسان بيشتر از تكك كشتى بـود. در تحقيق حاضر در تيمار كود زيستى به دليل اثرات هم

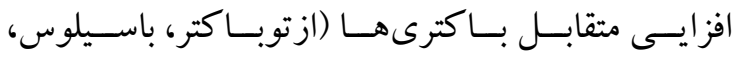
سودوموناس و تيوباسيلوس) تثبيت بيولوزيكى نيتـروزن، افزايش حلاليت فسفات، كاهش اسيديته خاكك و توليــ انـواع هورمـونهـا و مـواد محسر كك رشــد (سـيتو كينين، اكسين، بيوتين و اسيد بنتوتنيك)، باعث افزايش جـذب عناصر غذايى شده و با تأثير روى فتوسنتز باعث افزايش

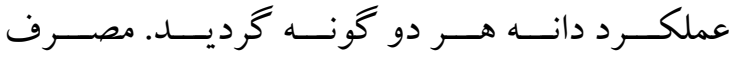
ورمى كميوست نيـز در مقايسـه بـا سـاير منـابع كـودى، باعث بهبود خصوصيات گياهى هر دو گونـه در شـرايط ديم شد. بنابراين، با توجه به كمبود مواد آلى در اغلـب ديمزارها و با در نظر كرفتن اثرات مثبـت منـابع كودى، به خصوص ورمى كميوست، مىتوان از اين منبع كودى اكولوزيكى جهت يايدارى توليد استفاده كرد و آنها را بهعنوان جايخزين كودهاى شيميايى در نظر كرفت.
مخلوط F رديف نخود : r رديف بزركك در شرايط عـدم مصـرف كـود بيشـترين ميـز ان نسـبت بر ابـرى زمـين كـل (1/Dه/ ) رادر بين نسبتهاى مخلوط داشت كه معـادل هذ درصد افزايش در بهـرهورى اسـتفاده از زمسين نسـبت بـه كشت خالص دو گونه بود (شكل (1). به نظر مىرسـد كـه كيـاه بـزرك از مزايـاى كشـت مخلـوط بـهنحسو مطلـوبى استفاده كرده و ايسن برتـرى نسـى بـراى مخلـوط ايسن دو كيـاه در شــرايط كمبـود منــابع غـذايى مناسـب بـه نظـر مىرسـد. از ديكـــ دلايـل افزايش سـودمندى اقتصـادى سيستمهاى كشت مخلوط مسى تـوان بـه انتخـاب دو كونسه زراعى با نيازهاى اكولوزيكك مختلف اشاره نمود. در ايسن

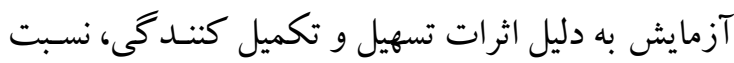

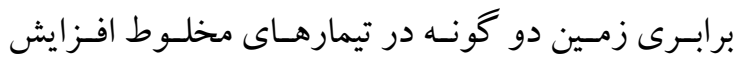
داشت. امينسىفر و همكاران (Aminifar et al., 2016) در

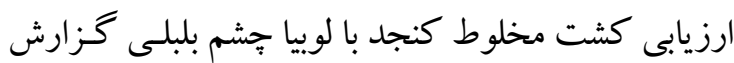
كردنسـ كـه بيشـترين نسـبت برابـرى زمسين كـل مربـوط بـه تيمـار كشـت مخلـوط •له درصسـ كنجـد: ·له درصــ لوبيا جششم بلبلى بـود كـه ناشـى از اثر مثبـت كيـاه لوبيـا

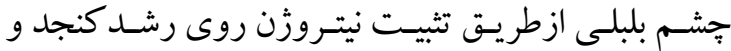

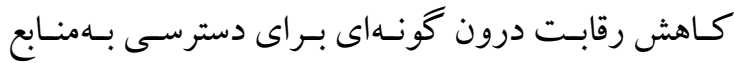
محيطى در اين نسبت بود. در كشت مخلوط جو و شنبليله كَزارش شـد كـه بيشـترين نسـبت برابـرى زمسين (I//N) مربوط بـه تركيـب كشـت مخلـوط ․ ا درصـد جـو: .0 درصـد شـنبليله در تيمـار وس تـن در هكتـار كـود دامسى بــود كـه نشـان دهنـده ايسن بـود كـهـ دو كيـاه در ايسن نســبت مخلـــوط بـــا كــارايى بيشـــترى از امكانــات موجسـود بهرهبــردارى كــرده و زيسـت تــوده بيشـترى توليـد كردنـل و در نتيجـه كشـت مخلـوط آنها بـر تـك كشـتى ارجحيـت داشـت (Ghanbari et al., 2016). در

\section{References}

Aminifar, J., M. Ramroudi, M. Galavi and G. R. Mohsenabadi. 2016. Assessment of cotton (Gossypium spp) productivity in rotation with intercropping of sesame (Sesamum indicum L.) and cowpea (Vigna unguiculata L.). Iran. J. Crop Sci. 18(2): 120-134. (In Persian with English abstract). 


$$
\text { "اثر الكوى كاشت و منبع كود بر...، اسدى و همكاران، 19با، ·ب-19" }
$$

Amirmardfar, R., A. Dabbagh Mohammadi Nassab, Y. Raei, S. Khaghaninia, R. Amini and S.H.

Tabataba Vakili. 2015. Evaluation of yield and yield components of oilseed rape in the wheat-oilseed rape strip intercropping influenced by chemical and biological fertilizers. J. Crop Ecophysio.8 (32): 437-450. (In Persian with English abstract).

Dabbagh Mohammadi Nassab, A., R. Amini and E. Tamar. 2015. Evaluation of maize (Zea mays L.) and three cultivars of common bean (Phaseolus vulgaris L.) intercropping with application of biofertilizers and chemical fertilizers. J. Agric. Sci. Sustain. Prod. 25(1): 99-112. (In Persian with English abstract).

Ghanbari, S., M. R. Moradi Telavat and S. A. Siadat. 2016. Effect of manure application on forage yield and quality of barley (Hordeum vulgare L.) and fenugreek (Trigonella foenum-graecum L.) in intercropping. Iran. J. Crop Sci.17 (4): 315 -328. (In Persian with English abstract).

Gholinezhad, E. and E. Rezaei-Chiyaneh. 2014. Evaluation of grain yield and quality of black cumin (Nigella sativa L.) in intercropping with chickpea (Cicer arietinum L.). Iran. J. Crop Sci. 16(3): 236-249. (In Persian with English abstract).

Hauggard-Nielson, H., P. Ambus and E. S. Jenson. 2001. Interspecific competition, N use and interference with weeds in pea-barley intercropping. Field Crops Res. 70: 101-109.

Heldt, H. W. and B. Piechulla. 2011. Plant Biochemistry (Fourth Ed.) Academic Press. 622 pp.

Hirpa T. 2014. Effect of intercrop row arrangemnt on maize and haricot bean productivity and the residual soil .World J. Agric. Sci. 4: 69-77.

Jahan, M. and M. Nasiri Mahalati. 2013. Soil fertility and biological fertilizers and agroecological approach. Mashhad Jadah Daneshghahi Press. pp 250. (In Persian).

Javanmard, A., A. Rostami, M. Nouraein and Gh. Gharekhani. 2016. Agronomical, ecological and economical evaluation of wheat- chickpea intercropping under rainfed condition of Maragheh. J. Agric. Sci. Sustain. Prod. 26(1): 19-37. (In Persian with English abstract).

Liu, Y. CH., M. X., Qin, J. X. Jing, L. Tang, Ch. Z. Wei, J. J. Wei and Y. Zheng. 2017. Intercropping influences component and content change of flavonoids in root exudates and nodulation of faba bean. J. Plant Interact. 12(1): 187-192.

Mahdavi Maraj, T., A. Ghanbari and M. R. Asghari Pour. 2015. Intercropping of barley and ajwain under different of manure and chemical fertilizers. J. Appl. Res. Plant Ecophysiol. 1 (4): 63-78. (In Persian with English abstract).

Mashhadi, T., A. Nakhzari Moghaddam and H. Sabouri. 2015. Investigation of competition indices in intercropping of wheat (Triticum aestivum L.) and chickpea (Cicer arietinum L.) under nitrogen consumption. J. Agroecol. 3(7): 344-355. (In Persian with English abstract).

Mazaheri, D. 1998. Intercropping. Tehran University Press. pp 310. (In Persian).

Nassiri Mahallati, M., A. Koocheki, P. Rezvani Moghaddam and A. Beheshti. 2001. Agroecology. Ferdowsi 


$$
\text { "مجله علوم زراعى ايران"، جلد بيست و يكم، شماره ا، بهار 1"11 }
$$

University of Mashhad Press, Mashhad, Iran. pp 460. (In Persian).

Nazeri, P., A. Kashani, K. Khavazi, M.R. Ardakani, M. Mirakhori and M. Pour Siahbidi. 2010. The effect of biofertilizer and phosphorus fertilizer banding with zinc on white bean (Phaseolus vulgaris L). J. Agroecol. 2: 175-185. (In Persian with English Summary).

Rezaei-Chiyaneh, E., M. Tajbakhsh, O. Valizadegan and F. Banaei Asl. 2014. Evaluation of different intercropping patterns of cumin (Cuminum cyminum L.) and lentil (Lens culinaris L.) in double crop. J. Agroecol. 5(4): 426-472. (In Persian with English abstract).

Rezaei-Chiyaneh, E., M. Tajbakhsh and S. Fotohi-Chiyaneh. 2015. Yield and yield components of fenugreek (Trigonella foenum-graecum L.) in strip intercropping with ajowan (Carum copticum L.) influenced by bio and chemical fertilizer. J. Agric. Sci. Sustain. Prod. 24(4): 1-15. (In Persian with English abstract).

Rezaei-Chiyaneh; E., S. Khorramdel and P. Garachali. 2015. Evaluation of relay intercropping of sunflower and faba bean on their yield and land use efficiency. J. Crops Improv.17 (1): 183-196. (In Persian with English abstract).

Rezvani Moghadam, P. and R. Moradi. 2013. Evaluation of planting date, biological fertilizer and intercropping on yield and essence quantity of cumin (Cuminum cyminum L.) and fenugreek (Trigonellafoenum-graecum L.). Iran. J. Field Crop Sci. 43(2): 217-230. (In Persian with English abstract).

Seyed noori, O., M. Mostafavi Rad and M. H. Ansari. 2016. Evaluation of grain yied, land equivalent ratio and fatty acids combination of peanut oil in intercropping with corn as affected by different levels of nitrogen. J. Crops Improv. 4(18): 805-820. (In Persian with English abstract).

Sosulski, F., W. and N. W. Holt. 1980. Amino acid composition and nitrogen-to-protein factors for grain legumes. Can. J. Plant Sci. 60: 1327-1331.

Tadayyon, M. R and A. J. Ghorbaninejad. 2012. Effect of supplementary irrigation and compost application on morphological traits and yield of two chickpea (Cicer arietinum L.) cultivars. Iran. J. Pulses Res. 2(3): 31 44. (In Persian with English abstract).

Tohidinejad, E., H. Madani and M. Jenabi. 2011. Organic fertilizers and vermicompost. Shahid Bahonar University of Kerman Publication. pp 150. (In Persian).

Vafadar-Yengeje, L., R. Amini and A. Dabbagh Mohammadi Nassab. 2017. Yield and yield components of faba bean (Vicia faba L.) in intercropping with moldavian balm (Dracocephalum moldavica) under organic and chemical fertilizers. J. Agric. Sci. Sustain. Prod. 27(4): 121-136. (In Persian with English abstract).

Zarifpour, N., M. T. Naseri Poor Yazdi and M. Nasiri Mahallati. 2014. Effect of different intercropping arrangements of cumin (Cuminum cyminum L.) and chickpea (Cicer arietinum L.) on quantity and quality characterastis of Species. Iran. J. Field Crops Res. 12(1):34-43. (In Persian with English abstract). 


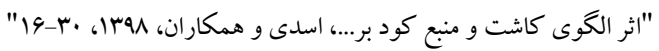

\title{
Effect of planting pattern and fertilizer source on agronomic characteristics of linseed (Linum usitatissimum L.) and chickpea (Cicer arietinum L.) in intercroppng under rainfed conditions
}

\section{S. Asadi ${ }^{1}$, E. Rezaei-chiyaneh ${ }^{2}$ and R. Amirnia ${ }^{3}$}

\begin{abstract}
S. Asadi, E. Rezaei-chiyaneh and R. Amirnia. 2019. Effect of planting pattern and fertilizer source on agronomic characteristics of linseed (Linum usitatissimum L.) and chickpea (Cicer arietinum L.) in intercroppung under rainfed conditions. Iranian Journal of Crop Sciences. 21(1): 16-30. (In Persian).
\end{abstract}

To study the effect of planting pattern and fertilizer source on agronomic characteritics of linseed and chickpea in intercropping in rainfed conditions, a field experiment was conducted as factorial arrangenents in randomized complete block design with three replications in Naqadeh, Iran in 2016-2017 cropping season. The first factor included six cropping patterns; one row chickpea: one row linseed, two rows chickpea: two rows linseed, four rows chickpea: two rows linseed, two rows chickpea: four rows linseed and sole cropping of each crops. The second factor included four fertilizer sources; without fertilizer (Control), 100\% chemical fertilizers (NPK), biofertilizers (Azoto Barvar1+ Phosphate Barvar2+ PotaBarvar2+ Sulfur Barvar1) and vermicompost $\left(10\right.$ t.ha $\left.^{-1}\right)$. The results showed that the effect of intercropping ratios and fertilizer sources were significant on seed yield, biological yield, oil content and oil yield of lineseed and seed yield and biological yield, number of rhizobium nodules and protein content of seed of chickpea. The highest seed yield of both species was obtained from sole cropping (linseed $945 \mathrm{~kg} \cdot \mathrm{ha}^{-1}$ and chickpea $629 \mathrm{~kg} \cdot \mathrm{ha}^{-1}$ ), however, the average seed yield of each crop, in the same per unit area, was higher than sole cropping (linseed 161. 5 and chicpea $128.5 \mathrm{~kg}^{-h^{-1}}$ ). The oil content of linseed $(6.60 \%)$ and seed protein content of chickpea $(20.26 \%)$ were higher in intercropping as compared with sole cropping. The use of fertilizer sources, especially the use of vermicompost, could increase the studied traits of both species in comparison with the control. The maximum LER (1.55) obtained from four rows of chickpea + two rows of linseed in control (without fertilizer). This means that intercropping improved land use efficiency by 55\% when compared with sole cropping. Considering the goals of sustainable agriculture and elimination of chemical inputs, the intercropping ratio of four rows of chickpea + two rows of linseed without fertilizer application was more suitable package.

Key words: Biofertilizer, Land equivalent ratio, Seed oil content, Seed Protein content and Vermicompost.

\footnotetext{
Received: April, $2018 \quad$ Accepted: January, 2019

1. MSc Student, Urmia University, Urmia, Iran

2. Assistant Prof., Urmia University, Urmia, Iran (Corresponding author) (Email: e.rezaeichiyaneh@urmia.ac.ir)

3. Associate Prof., Urmia University, Urmia, Iran
} 